\title{
Complications of ent foreign bodies: a retrospective study
}

\author{
Ricardo Rodrigues Figueiredo ', Andréia \\ Aparecida de Azevedo ${ }^{2}$, Artbur Octavio de Ávila \\ Kós ${ }^{3}$, Shiro Tomita ${ }^{4}$
}

Keywords: complications, foreign bodies, otolaryngology.

\section{Summary}

\begin{abstract}
F reign bodies are one of the most common ENT (Ear Nose and Throat) urgencies. Serious complications may occur, like tympanic perforations and bronchoaspiration, but they are uncommon. Aim: To analyze a 1356 foreign body series and establish causes for the complications, looking at prevention. Materials and methods: 1356 patients with ear, nose and throat foreign bodies from the ENT Department of Souza Aguiar Hospital, in Rio de Janeiro, between 1992 and 2000 , were analyzed in a retrospective study for parameters like age, gender, type and localization of the foreign body, time span between introduction and removal of the foreign body and complications. Results: The most common foreign bodies were beans and the most frequent age was between 1 and 4 years old. Ear foreign bodies were the most common, followed by nasal foreign bodies. Complications were statistically related to time, child's age and practical experience of the physician. Conclusion: Most of the situations related to ENT foreign bodies are avoidable. Improvements in Public Health Assistance and otolaryngologists' training are essential to avoid serious complications.
\end{abstract}

\footnotetext{
${ }^{1}$ Master's degree in Otorhinolaryngology, UFRJ, Assistant Professor and Head of the ENT Service, Valenca Medical School, RJ. ${ }^{2}$ Physician, otorhinolaryngologist. OTOSUL, Sul-Fluminense Otorhinolaryngology.

${ }_{3}^{3}$ Doctoral degree in Otorhinolaryngology, Professor Emeritus of Otolaryngology, Medical School, Rio de Janeiro Federal University, UFRJ.

${ }^{4}$ Doctoral degree in Otorhinolaryngology, Full Professor and Head of the Otorhinolaryngology Service, Medical School, UFRJ Clementino Fraga Filho University Hospital, Rio de Janeiro Federal University, Souza Aguiar Municipal Hospital. Address for correspondence: Rua 60 n 1680 ap. 202 Bairro Sessenta Volta Redonda RJ 27261-130.
}

Paper submitted to the ABORL-CCF SGP (Management Publications System) on September 13th, 2006 and accepted for publication on November 9th, 2006. cod. 3392. 


\section{INTRODUCTION}

According to the literature, ${ }^{1-4}$ foreign bodies are responsible, on average, for $11 \%$ of otorhinolaryngological emergencies; complications ensue in $22 \%$ of cases. Most of these complications are easily resolved, but occasionally severe conditions may emerge, such as tympanic perforation and bronchoaspiration. ${ }^{4,5}$

Decisive factors contributing to complications ${ }^{3,4}$ are:

removal attempts by laypersons and untrained health professionals; bodies;

- lack of medical experience in managing foreign

lack of adequate hospital infrastructure;

poor structure of the public health sector for dealing with otorhinolaryngological emergencies;

- foreign body remaining within the site for a long period, frequently due to the previous item.

Our purposes in this paper were:

to describe our 8-year experience in managing foreign bodies of the ear, nose, pharynx and larynx;

to analyze the main factors leading to complications by studying 1,356 foreign body removal cases and seeking forms of avoiding those complications.

\section{PATIENTS, MATERIAL AND METHOD}

We conducted a retrospective analysis of 1,356 foreign body cases seen at our Unit between December 1992 and December 2000. Six parameters were taken into account: age, sex, site of foreign body (FB), type of $\mathrm{FB}$, complications, duration of the period between FB introduction and removal and date of removal (between 1992 and 2000). About this last parameter, its aim was to establish a relation between the otorhinolaryngologist's experience and the presence of complications, given that the same medical doctor (the author) removed all FB. We also analyzed the relation between complications and other parameters; complications were classified as iatrogenic and non-iatrogenic (the set of complications was named "complications in general"). The chi-square (X2) test and Fisher's exact test were used for statistical analyzing the relation between complications on the one hand and sex, age, type of FB, site, duration until removal and date of FB removal on the other. The significance level was $5 \%$, that is, there was no statistical significance when the statistical test $\mathrm{p}$ value was equal to or below 0.05 .

The surgical materials used for FB removal included nasal and auricular speculae, Bruennings tongue retractors, rigid $4 \mathrm{~mm}$ diameter optic fibers $\left(70^{\circ}, 0^{\circ}\right.$ and $30^{\circ}$ ), Kelly and bayonet forceps, an optic fiber laryngoscope, Hartmann and alligator forceps, blunt and pointed hooks, syringes for ear lavage and an electrical ear cleaner. The Research Ethics Committee of the Souza Aguiar
Municipal Hospital approved this study (protocol number 32/2003).

\section{RESULTS}

OF $1,356 \mathrm{FB}$ cases, $753(55.53 \%)$ were in the ear, 420 (30.97\%) were nasal, 179 (13.21\%) were pharyngeal, and $4(0.29 \%)$ were laryngeal FBs. There were 129 pharyngeal FBs lodged in the tonsils (72.06\%), of which 65 were in the right tonsil and 64 in the left tonsil. There were $31 \mathrm{FB}$ cases $(17.32 \%)$ in the base of the tongue, $12(6.70 \%)$ in the vallecula, $3(1.68 \%)$ in the right supratonsillar recess (STR), 2 (1.12\%) in the hypopharynx, and 2 (1.12\%) in tonsillar areas (tonsillectomized patients), of which 1 was to the right and 1 to the left.

There were 674 cases (49.70\%) in females and 682 cases $(51.30 \%)$ in males. The age distribution may be seen in Chart 1.

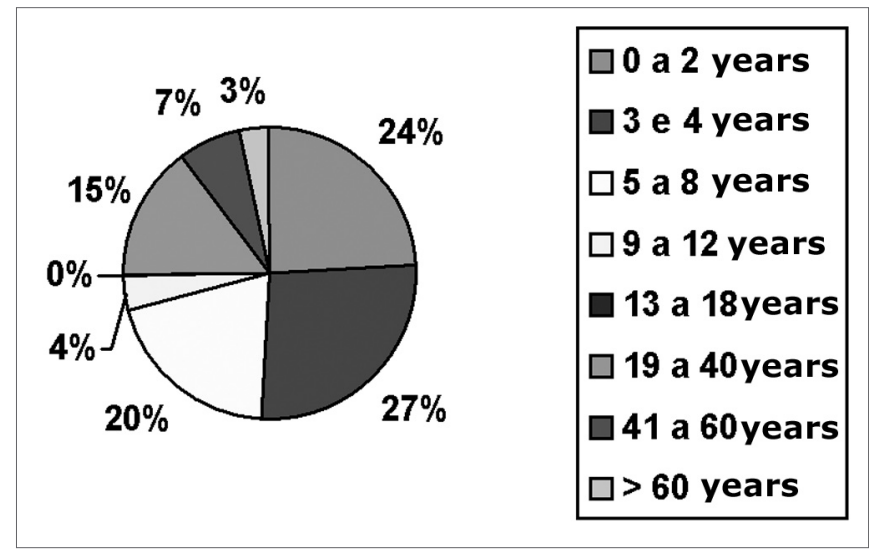

Chart 1- Distribution by age range

The type of FBs may be seen in Chart 2. The acronym SPA means "Small Plastic Artifacts." Beans and corn grains were not included in this chart and were analyzed separately.

Live FBs are described in Chart 3.

There were no complications in 1,055 cases (77.80\%). Complications were seen in 301 cases (22.20\%), including those resulting from removal procedures. Complications were iatrogenic in 159 cases (11.70\%). The types of complications may be seen in Chart 4 .

Chart 5 shows the time elapsed between FB introduction and removal. The mean duration was 9.71 hours.

Table 1 shows the frequency (n) and the percentage (\%) for sex, age, type, site, duration and date related to the presence and absence of complications in general. The chi-square (X2) test was used for the statistical analysis. After this point, bean and corn grains were included in the item "seeds".

Table 2 shows the frequency (n) and the percentage 


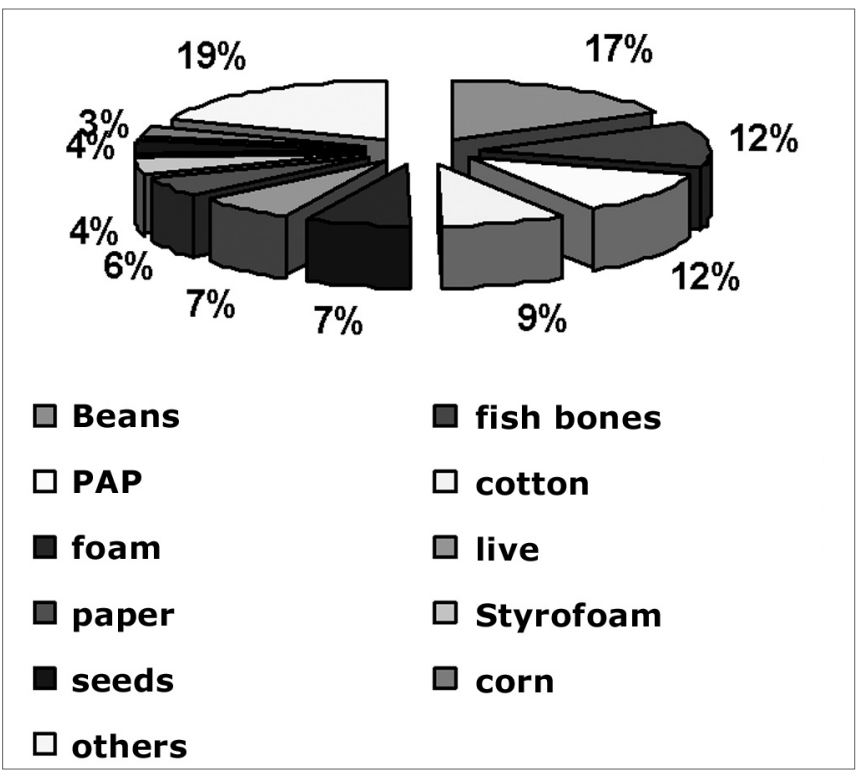

Chart 2. FB types

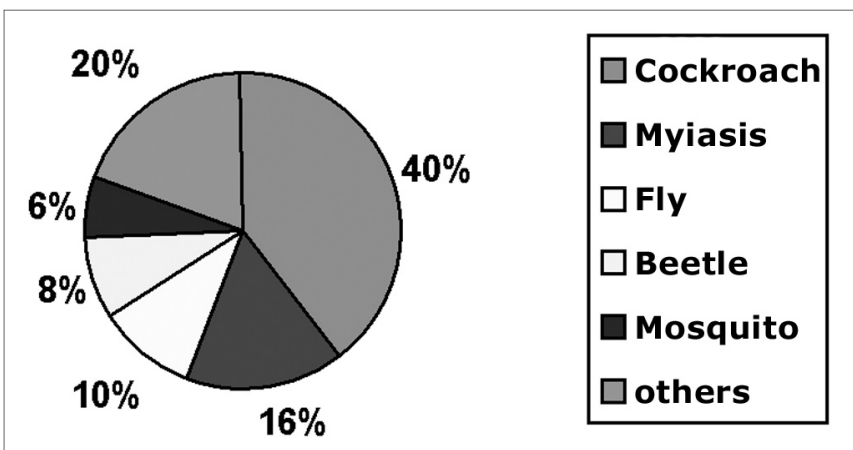

Chart 3. Live FB

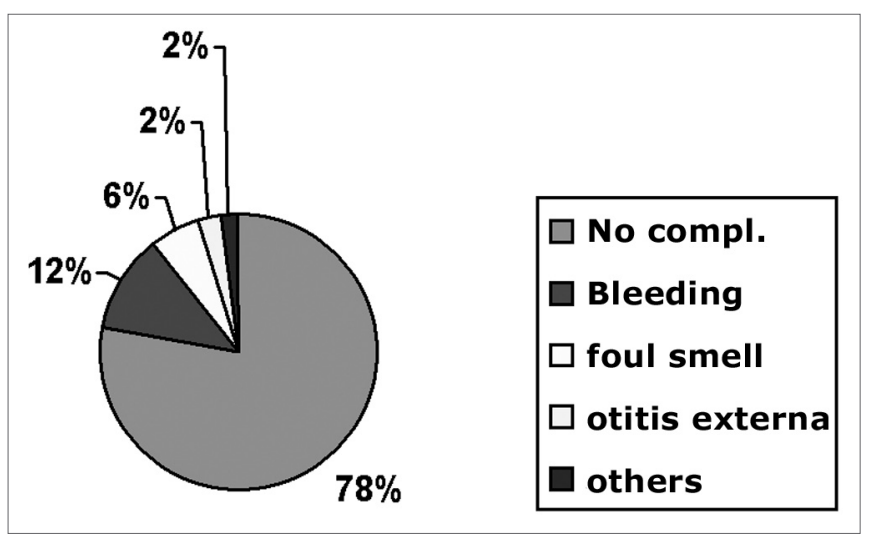

Chart 4. Complications

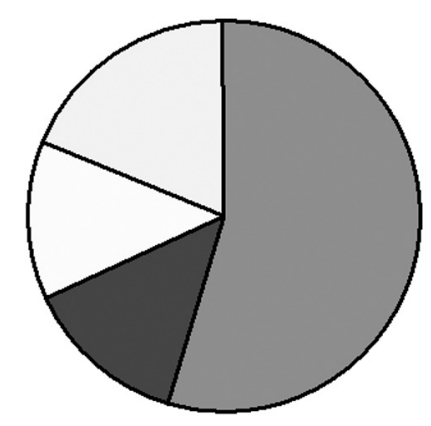

\section{<24hs $54.50 \%$ \\ $\square 24$ a $72 \mathrm{hs} 13.57 \%$ $>72 \mathrm{hs} 13,06 \%$ $\square$ Ignored}

Chart 5. Time span between FB introduction and removal

(\%) for sex, age, type, site, duration and date related to the presence and absence of iatrogenic complications. The chi-square (X2) test was used for the statistical analysis.

These results up to this point showed that the noniatrogenic complications groups had particular features. The three groups, therefore, were analyzed separately to improve characterization according to the variables we investigated.

Table 3 shows the frequency (n) and the percentage (\%) for sex, age, type, site, duration and date related to the presence and absence of iatrogenic and non-iatrogenic complications, and no complications. The chi-square (X2) test and Fisher's exact test was used for the statistical analysis.

There was no significant association $(\mathrm{p}=0.22)$ between sex and the type of complication.

\section{DISCUSSION}

The study of FBs is fascinating, presenting many regional peculiarities. Otorhinolaryngology deals with most of the natural orifices that are habitually exposed, such as the mouth, nostrils and ears. ${ }^{4}$ The esophagus and lower airways are affected indirectly, as FBs must first pass through the pharynx or the nasal fossae. Oropharyngeal and nasal fossae FBs are potentially esophageal and bronchial FBs. ${ }^{3-5}$

FBs in the ear may lead to tympanic perforation and deafness, particularly if there is secondary infection. Severe nose bleeding associated with FBs is not uncommon; fish spine may lead to peritonsillar abscesses. ${ }^{4,6,7}$

Our findings about the site of FBs are in agreement with the literature, ${ }^{8-12}$ in which ear FBs predominated, followed by those in the nose and throat. In our opinion, nose and throat FBs are more easily eliminated by physio- 
Table 1. Statistical analysis for complications in general.

\begin{tabular}{|c|c|c|c|c|c|c|c|}
\hline \multirow{2}{*}{ Code } & \multirow{2}{*}{ Variables } & \multirow{2}{*}{ category } & \multicolumn{2}{|c|}{ with complications } & \multicolumn{2}{|c|}{ no complications } & \multirow{2}{*}{$p$ value } \\
\hline & & & $\mathrm{n}$ & $\%$ & $\mathrm{n}$ & $\%$ & \\
\hline \multirow[b]{2}{*}{$x 2$} & sex & male & 518 & 49.1 & 164 & 54.5 & \multirow[b]{2}{*}{0.099} \\
\hline & $(n=1356)$ & Female & 537 & 50.9 & 137 & 45.5 & \\
\hline \multirow{6}{*}{ x3_a } & \multirow{6}{*}{ age $(n=1356)$} & $<=2$ years & 99 & 32.9 & 212 & 20.1 & \multirow{6}{*}{$<0.0001$} \\
\hline & & 3 a 6 & 126 & 41.9 & 377 & 35.7 & \\
\hline & & 7 a 10 & 36 & 12.0 & 95 & 9.0 & \\
\hline & & 11 a 18 & 9 & 3.0 & 78 & 7.4 & \\
\hline & & 19 a 50 & 27 & 9.0 & 216 & 20.5 & \\
\hline & & $>50$ & 4 & 1.3 & 77 & 7.3 & \\
\hline \multirow{4}{*}{$x 4$} & & Live & 22 & 35.5 & 74 & 21.2 & \multirow{4}{*}{$<0.0001$} \\
\hline & Type & Fish spine & 6 & 9.7 & 159 & 45.6 & \\
\hline & $(n=411)$ & SPA & 22 & 35.5 & 76 & 21.8 & \\
\hline & & Seeds & 12 & 19.4 & 40 & 11.5 & \\
\hline \multirow{3}{*}{ x6_a } & & ear & 157 & 52.3 & 596 & 56.7 & \multirow{3}{*}{$<0.0001$} \\
\hline & Site $(n=1352)$ & Nose & 137 & 45.7 & 283 & 26.9 & \\
\hline & & Pharynx & 6 & 2.0 & 173 & 16.4 & \\
\hline \multirow{3}{*}{$x 8 \_a$} & Duration (n - & $<=24 \mathrm{~h}$ & 109 & 52.9 & 709 & 79.0 & \multirow{3}{*}{$<0.0001$} \\
\hline & 1103) & 24 a 72 h & 35 & 17.0 & 106 & 11.8 & \\
\hline & & $>72 \mathrm{~h}$ & 62 & 30.1 & 82 & 9.1 & \\
\hline \multirow{4}{*}{$x 9$} & & 92 a 94 & 103 & 34.2 & 349 & 33.1 & \multirow{4}{*}{0.004} \\
\hline & Date $(\mathrm{n}=$ & 94 a 96 & 63 & 20.9 & 323 & 30.6 & \\
\hline & 1356) & 96 a 98 & 88 & 29.2 & 266 & 25.2 & \\
\hline & & 98 a 00 & 47 & 15.6 & 117 & 11.1 & \\
\hline
\end{tabular}

A significant association was found between:

- child age and presence of complications in general $(p=0.0001)$.

- the type of FB (live and SPA) and presence of complications in general ( $p=0,0001$ ).

- the site of the FB (nose) and presence of complications in general $(p<0.0001)$.

- the time until removal and presence of complications in general $(p<0.0001)$. This means that there was a significant relation between complications in general and duration $>24$ hours. On the other hand, there was also a time $<24$ hours relation in the group with no complications.

- the date and presence of complications in general $(p=0.004)$. This means that there was a significant relation between complications in general and time from 1996 to 2000. No significant association was found between sex and complications in general $(p=0.099)$. 
Table 2. Statistical analysis of iatrogenic complications.

\begin{tabular}{|c|c|c|c|c|c|c|c|}
\hline \multirow[t]{2}{*}{ Cod. } & \multirow[t]{2}{*}{ Variables } & \multirow[t]{2}{*}{ category } & \multicolumn{2}{|c|}{ latrogenic complication } & \multicolumn{2}{|c|}{$\begin{array}{c}\text { Non-iatrogenic complication o } \\
\text { no complication }\end{array}$} & \multirow[t]{2}{*}{$p$ value } \\
\hline & & & $\mathrm{n}$ & $\%$ & $\mathrm{n}$ & $\%$ & \\
\hline $\mathrm{x} 2$ & $\operatorname{Sex}(n=1356)$ & Female & 70 & 44.0 & 604 & 50.5 & 0.12 \\
\hline \multirow{5}{*}{ x3_a } & \multirow{5}{*}{ Age $(n=1356)$} & $<=2$ years & 41 & 25.8 & 270 & 22.6 & \multirow{5}{*}{$<0.0001$} \\
\hline & & 7 a 10 & 21 & 13.2 & 110 & 9.2 & \\
\hline & & 11 a 18 & 3 & 1.9 & 84 & 7.0 & \\
\hline & & 19 a 50 & 9 & 5.7 & 234 & 19.6 & \\
\hline & & $>50$ & 2 & 1.3 & 79 & 6.6 & \\
\hline \multirow{2}{*}{$x 4$} & \multirow{2}{*}{ Type $(n=411)$} & Live & 5 & 11.9 & 91 & 24.7 & \multirow{2}{*}{$<0.0001$} \\
\hline & & Seeds & 10 & 23.8 & 42 & 11.4 & \\
\hline \multirow{3}{*}{ x6_a } & \multirow{3}{*}{ Site $(n=1352)$} & ear & 98 & 62.0 & 655 & 54.9 & \multirow{3}{*}{0.001} \\
\hline & & Nose & 54 & 34.2 & 366 & 30.7 & \\
\hline & & Pharynx & 6 & 3.8 & 173 & 14.5 & \\
\hline \multirow{3}{*}{$x 8 \_a$} & \multirow{2}{*}{ Duration $(\mathrm{n}=$} & $<=24 \mathrm{~h}$ & 100 & 80.7 & 718 & 73.3 & \multirow{3}{*}{0.20} \\
\hline & & 24 a 72 h & 11 & 8.9 & 130 & 13.3 & \\
\hline & 1103) & $>72 \mathrm{~h}$ & 13 & 10.5 & 131 & 13.4 & \\
\hline \multirow{2}{*}{$x 9$} & & 92 a 94 & 68 & 42.8 & 384 & 32.1 & \multirow{2}{*}{$<0.0001$} \\
\hline & Date $(\mathrm{n}=$ & 94 a 96 & 27 & 17.0 & 359 & 30.0 & \\
\hline
\end{tabular}

A significant association was found between:

- child age and presence of iatrogenic complications $(p=0.0001)$.

- the type (SPA and seeds) and presence of iatrogenic complications ( $p=0.0001)$.

- the site (ear) and presence of iatrogenic complications $(p=0.001)$.

- the date and presence of iatrogenic complications $(p=0.0001)$. This means that there was a significant relation between iatrogenic complications and the date from 1992 to 1992-1994.

- There was no significant association between sex $(p=0.12)$ and duration $(p=0.20)$, and presence of iatrogenic complications. 
Table 3. Statistical analysis of complications (iatrogenic, non-iatrogenic) and no complications.

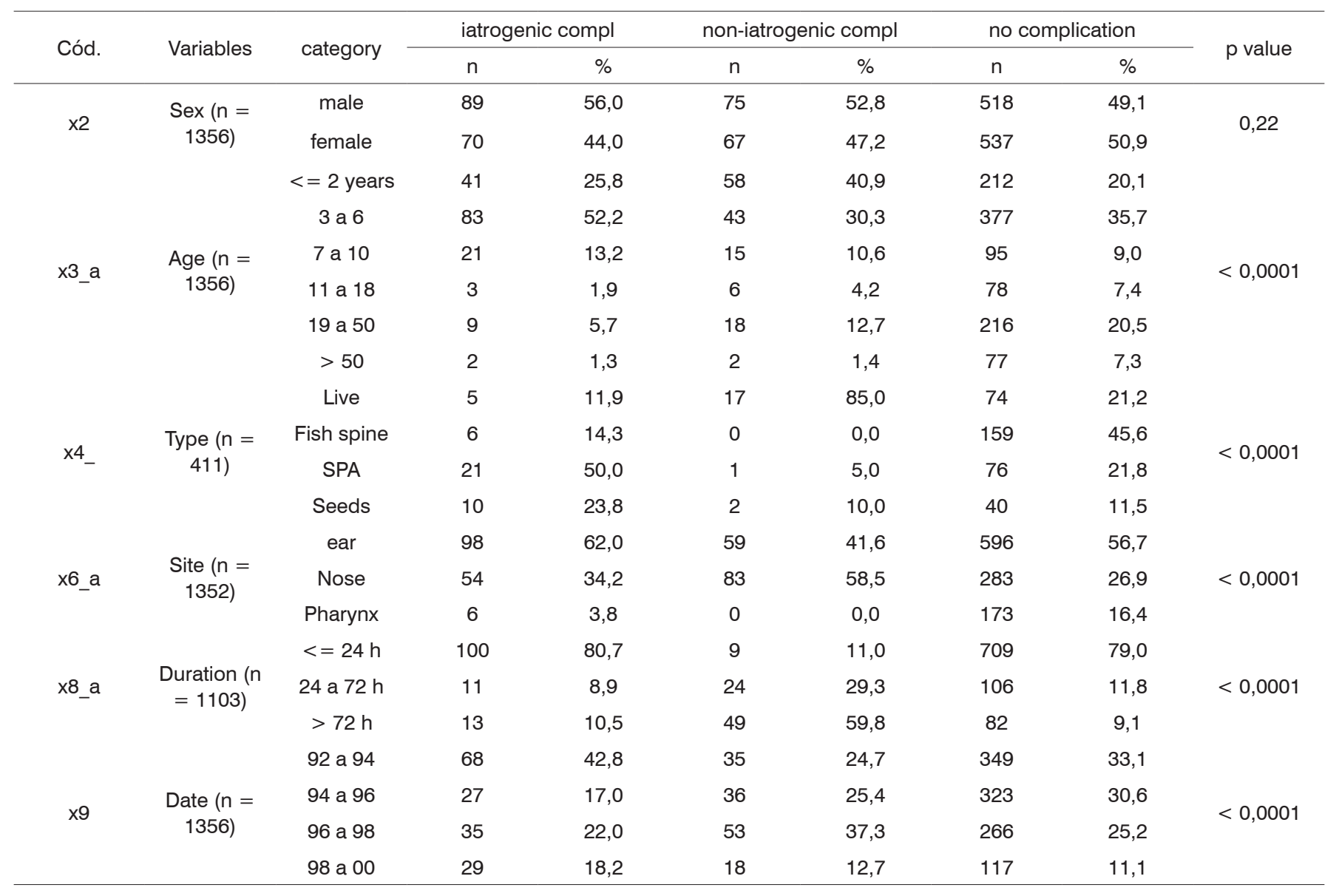

A significant association was found between:

- child age and presence of complications ( $p<0.0001)$. This means that there was a significant relation between age (until age 10 years) and complications (iatrogenic and non-iatrogenic). On the other hand, the group with no complications was related with adults.

- the type and presence of complications $(p<0.0001)$. This means that there was a significant relation between iatrogenic complications and SPA and seeds, and that there was a significant relation between non-iatrogenic complications and insects. On the other hand, the group with no complications was related with fish spine.

- the site and presence of complications $(p<0.0001)$. This means that there was a significant relation between iatrogenic complications and the ear, and that there was a significant relation between non-iatrogenic complications and nose. On the other hand, the group with no complications was related with the pharynx.

- the duration and presence of complications $(p<0.0001)$. This means that there was a significant relation between non-iatrogenic complications and duration $>24$ hours. On the other hand, the groups with no complications and with iatrogenic complications were related with duration $<24$ hours.

- the date and presence of complications $(p<0.0001)$. This means that there was a significant relation between iatrogenic complications and the date (1992-1994), and that there was a significant relation between non-iatrogenic complications and the date (1996-1998). On the other hand, the group with no complications was related with the date (1994-1996). 


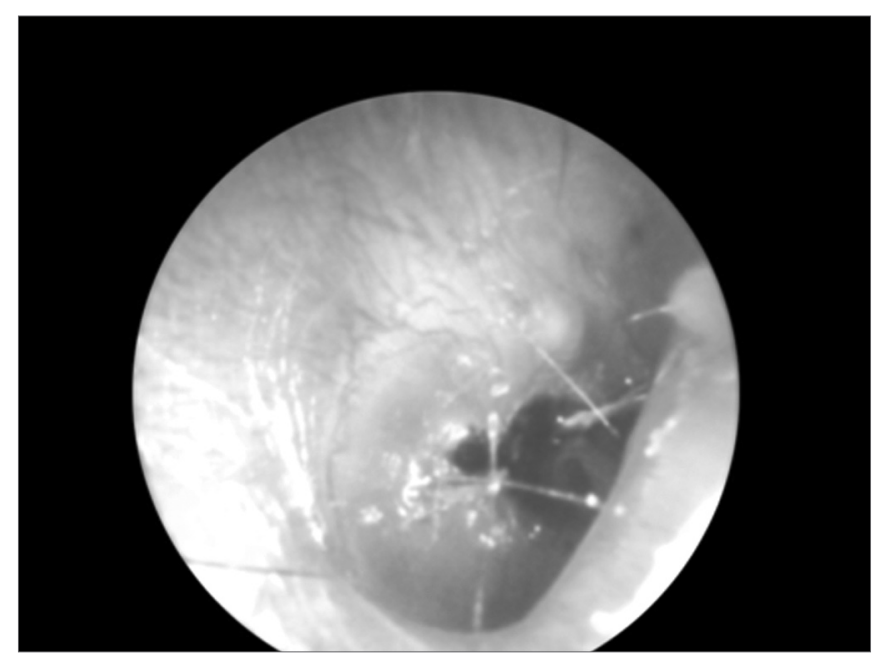

Figure 1. Tympanic perforation by a foreign body (bamboo fragment).

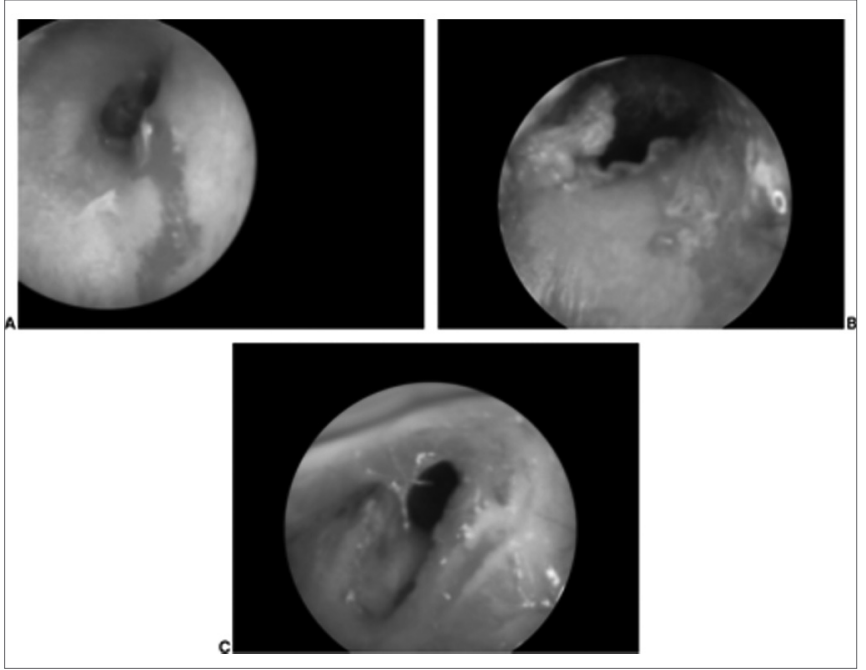

Figure 2. External auditory canal skin laceration.

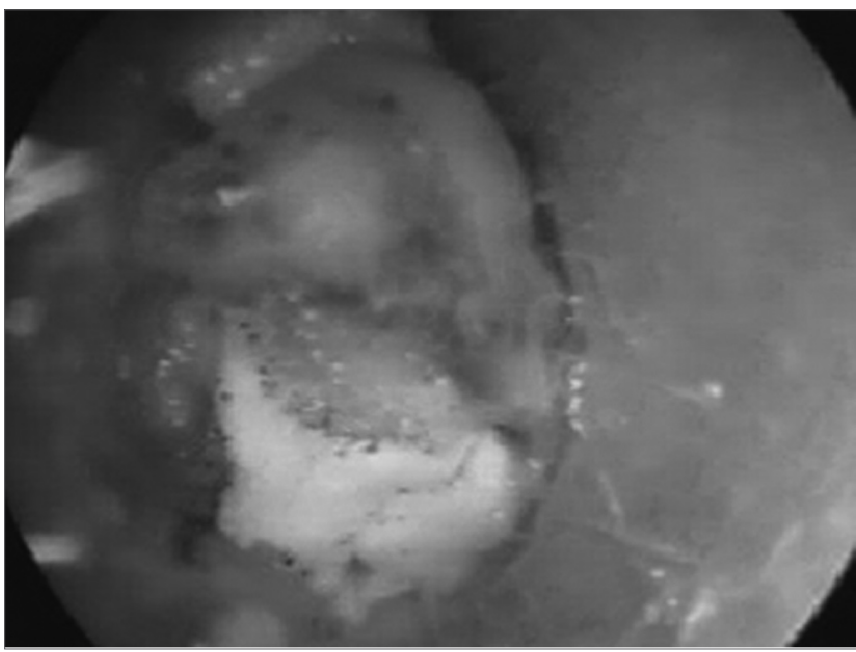

Figure 3. Foreign body associated otomycosis (cotton fragment).

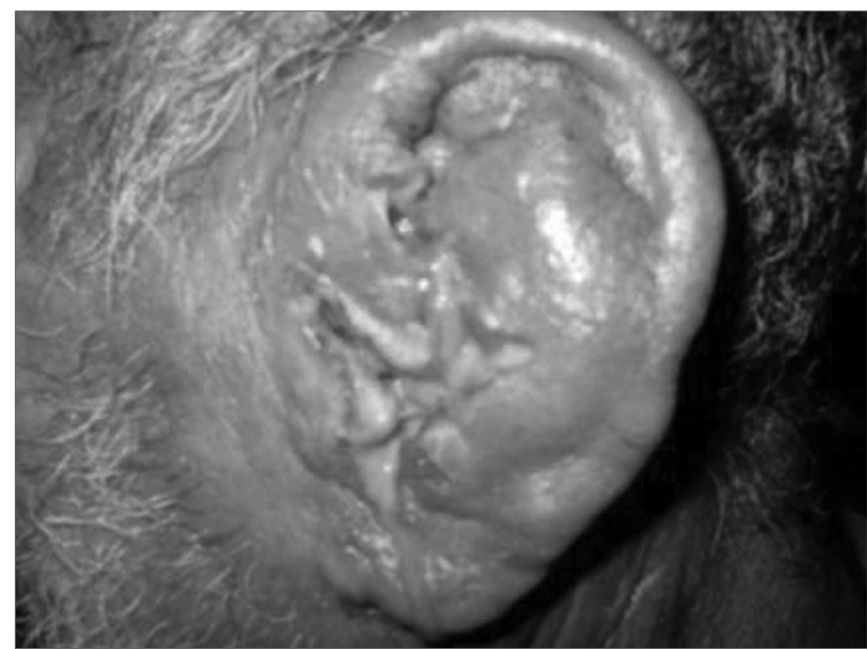

Figure 4. Perichondritis secondary to myiasis.

logical mechanisms, such as sneezing, coughing and the nausea reflex. The natural projection of tonsils into the oral cavity explains its position as the most common site for impacted pharyngeal FBs. There were no statistically significant differences in the sex distribution, which is in agreement with the literature..$^{2-4,11,13}$

The age distribution showed a clear predominance of children aged between 1 and 4 years ( $47.64 \%$ of cases). Nasal FBs are almost exclusively found in children; pharyngeal FBs are more commonly found in adults; the distribution of ear FBs is more balanced, with a slight predominance in children. These findings are also in agreement with the literature ${ }^{8,9,13}$

Beans were the most common FB (17.18\%), the most frequent $\mathrm{FB}$ in the ear (23.11\%) and the third most frequent $\mathrm{FB}$ in the nose (14.76\%). A high rate of fish spine as pharyngeal FBs usually reflects lack of care in preparing meals, specifically small fish, which are usually the least expensive. SPA are parts of toys and various other objects, such as buttons and food package seals. Toys and other objects bought from street vendors are especially dangerous; most of them contain no recommendations about age. Cotton fragments reflect popular cleaning habits and methods for relieving otological pruritus. Foam fragments, usually from ruptured pillows and mattresses, were the most common nasal FBs found.

Live FBs require specific comments. At our unit, the most common live FBs were cockroaches, followed by myiasis, mosquitoes and beetles. ${ }^{4,15}$ Cockroaches generally enter the external auditory canal from the ground, particularly in people who habitually (or for lack of choice) sleep on the floor ${ }^{15,16}$ The clinical picture is dramatic and painful; the recommended approach is to first kill the insect by instilling oily substances, alcohol or ether into the external auditory canal. Live FBs are generally related to poor hygiene. ${ }^{4,15}$ The most frequently found fly associated with 
myiasis in Brazil is the Cochliomya hominivorax, found in ear and nasal fossae infestations. ${ }^{15,16}$ Complications of myiasis in the nose are common, such as septal perforation, necrosis of the turbinates and orbitary complications. Larvae should be surgically removed as much as possible and parenteral antibiotics (clyndamicin or crystalline penicillin associated with ceftriaxone) should be given. ${ }^{4,15}$ Some studies have suggested using ivermectine. ${ }^{17}$

Complications were found in $22.20 \%$ of cases. Marques et al. noted a higher rate of complications in cases that had been previously manipulated by non-otorhinolaryngologists, other health professionals, the patients themselves and other laypersons. ${ }^{8,9,14}$

In our data, the most frequent complications were bleeding (51.83\% of complications), fetidness $(28.57 \%)$ and external otitis (10.30\%). There were fewer serious complications such as necrosis (1.33\%) and tympanic perforation $(0.99 \%)$. Bleeding usually is mild; in our series there was no need for contention measures. Fetidness occurs due to secondary bacterial infection, more commonly in nasal FBs, especially with hygroscopic materials such as foam fragments, paper and cotton. ${ }^{2-4}$ Some types of complications are shown below:

There was no statistically significant difference between sexes relative to complications. The statistically significant difference between complications and age below 10 years is probably due to agitation of the child during removal. A relation between the presence of iatrogenic complications and certain types of FBs (such as SPA and seeds) has led us to conclude that these FBs are technically more difficult to remove. Non-iatrogenic complications showed a statistically significant with live FBs, possibly due to an association with inflammation and infection.

Our data reveal a statistically significant relation between non-iatrogenic complications and nasal FBs, probably due to a higher incidence of secondary infection, which results in fetidness. Ear FBs were associated with iatrogenic complications, probably due to the tortuous anatomy of the external auditory canal, which makes removal more troublesome.

On the time period between FB insertion and removal, there was a statistically significant relation between non-iatrogenic complications and longer permanence FBs (over 72 hours); we conclude that delays in removing FBs increase the frequency of non-iatrogenic complications, which reinforces the importance of prompt treatment. There was a statistically significant relation between iatrogenic complications and FBs in place for less than 24 hours. We believe that this occurs because patients are more agitated soon after FB insertion. The incidence of FBs removed with no complications is also related to early treatment.

Finally, there was a higher incidence of iatrogenic complications in the first two years of our series, from 1992 to 1994 . These findings indicate that professional experience in managing FBs is important; two reasons are given: improved manual dexterity with experience, and better decision-making about using sedation or general anesthesia. These findings reinforce the need for higherquality teaching about urgencies in graduation courses.

Data on the time between FB insertion and removal show that removal takes place within the first 24 hours in $54.50 \%$ of cases, between 24 and 48 hours in $13.57 \%$ of cases, and after 72 hours in $13.06 \%$ of cases. This time period could not be established in $18.95 \%$ of cases, particularly in children that are wary of explaining their acts to caretakers.

\section{CONCLUSION}

Our data describes the series in one of the major South American ENT urgency service. Findings in general are in agreement with the literature; there are local peculiarities, such as a predominance of beans as the most frequent FB. Iatrogenic complications were related to ear FBs, children, SPA, seeds, less than 24 hours elapsed between FB insertion and removal, and lack of professional experience in managing FBs. Non-iatrogenic complications were related with live FBs and long duration.

Based on the abovementioned conclusions, certain measures are suggested that might avoid complications, as follows:

1) Informing patients to immediately seek an otorhinolaryngologist in FB cases, especially for the treatment of live FBs.

2) Increased care by otorhinolaryngologists with technically difficult to remove FBs, such as seeds and SPA, especially in ears and in children, in whom removal under sedation or general anesthesia should be considered.

3) Improved teaching about urgencies in ENT graduation courses.

\section{ACKNOWLEDGMENTS}

We would like to dedicate this paper to our colleagues, nurse assistants and patients of the Souza Aguiar hospital.

\section{REFERENCES}

1. Bressler K, Shelton C. Ear foreign-body removal: a review of 98 consecutive cases. Laryngoscope 1993;103(4 Pt 1):367-70.

2. Hanke Filho EH, CMR, Hanke EMR, Hanke MMR. Corpos Estranhos de Nariz, Ouvidos, Faringe e Seios Paranasais. Rev Soc Otorrinolaringol RJ 2002;2:73-7.

3. Marques MPCS, MC Nogueira MD, Nogueirol RB, Maestri VC. Tratamento dos corpos estranhos otorrinolaringológicos - um estudo prospectivo. Rev Bras Otorrinolaringol 1998;64(1):25-9.

4. Figueiredo R. Corpos estranhos de orelha, nariz, faringe e laringe. In: Figueiredo R. Urgências e Emergências em Otorrinolaringologia. Primeira edição, Rio de Janeiro: Editora Revinter; 2006.

5. Figueiredo RM, Machado VS. Aspiração de corpo estranho através de traqueotomia: descrição de um caso. Rev Bras Otorrinolaringol 
2005;71(2):234-6.

6. Hungria H. Otorrinolaringologia. 6 ed. Rio de Janeiro: Guanabara Koogan; 1992.

7. Bremond GWM, Chobaut JC, Magnan J, Acquaviva F. Pathologie de loreille externe. In: Bach J-FI, J-C; Jasmin C, Ménard J, Neveux J-Y (editor). Encyclopedie Médico-Chirurgalle. Paris: Editions Techniques; 1980. p. 20070

8. Austin D. Diseases of the external ear. In: Ballenger JS, JB, editor. Otorrhinolaryngoly Head and Neck Surgery. 15th ed. Baltimore: Williams \& Wilkins; 1996. p. 974-88.

9. Lopes Filho OC, C.H. Inflamações Agudas das Fossas Nasais. In Lopes Filho O, editor. Tratado de Otorrinolaringologia. São Paulo: Roca; 1994. p. 274-82.

10. Hanke Filho EH, CMR, Hanke EMR, Hanke MMR. Corpos Estranhos de Nariz, Ouvidos, Faringe e Seios Paranasais. Rev Soc Otorrinolaryngol RJ 2002;2:73-7.

11. Hughson W. Examination of the ear and of the function of hearing In: Jackson CJ, CL, editor. Diseases of the Nose, Throat and Ear. Philadelphia: W.B. Saunders Co.; 1945. p. 221-32.
12. Balbani AK, M, Angélico JrFV, Sanchez TG, Voegels RL, Butugan O, Câmara J. Atendimento para retirada de corpos estranhos de ouvido, nariz e faringe em crianças. Revista de Pediatria do Centro de Estudos Prof. Pedro Alcântara - Instituto da Criança do Hospital das Clínicas da FMUSP 1998;20(1):8-13.

13. Stool SE, McConnel CS Jr. Foreign bodies in pediatric otolaryngology. Some diagnostic and therapeutic pointers. Clin Pediatr (Phila)1973;12(2):113-6.

14. Stool SE, Belafsky ML. Pediatric otolaryngology. Curr Probl Pediatr $1971 ; 2(2): 1-51$.

15. Figueiredo RR, DS, Couri MS, Azevedo AA, Mossumez F. Corpos estranhos animados em Otorrinolaringologia. Rev Bras Otorrinolaringol 2002;68(5):722-29.

16. Guimarães JH, Papavero N. Myiasis in man and animals in the neotropical region. In: Bibliographic database. São Paulo: Editora Plêiade/FAPESP; 1999. p. 1-308.

17. Ramalho JRO et al. Míase nasal: relato de um caso. Rev Bras Otorrinolaringol 2001;67(4):581-4. 